Al-Madrasah: Jurnal Ilmiah Pendidikan Madrasah Ibtidaiyah

Vol. 6, No. 1, 2022

DOI 10.35931/am.v6i1.842

P-ISSN: 2620-5807; E-ISSN: 2620-7184

\title{
KONSEP PENDIDIKAN KECERDASAN INTERPERSONAL PADA SISWA USIA MADRASAH MENURUT MAHMUD AL MISHRI
}

\author{
Hasbi Indra ${ }^{1}$, Akhmad Alim ${ }^{2}$, Salman Al Farisi ${ }^{3}$ \\ ${ }^{123}$ Universitas Ibn Khaldun Bogor,Jawa Barat, Indonesia. \\ Email: hasbi.indra@uika-bogor.ac.id ${ }^{1}$, alim@uika-bogor.ac.id², \\ abu.fariz90@gmail.com ${ }^{3}$
}

\begin{abstract}
Abstrak
Bangunan kecerdasan anak di tingkat madrasah tidak hanyar berfokus kepada 1 kecerdasan saja, akan tetapi sudah mengarah kepada pembentukan multiple intelegence, salah satunya ada kecerdasan interpersonal. Kecerdasan interpersonal adalah kemampuan manusia untuk beradaptasi dengan lingkungan dan manusia sekitar. Fokus kajian artikel ini ialah membahas konsep pendidikan kecerdasan interpersonal remaja awal dalam perspektif Mahmud al-Mashri dalam buku beliau yang berjudul Adab alThifli al-Muslim Lishigor Walkibar. Metode penelitian menggunakan kualitatif dengan pendekatan deskriptif analisis dan dalam pengumpulan datanya peneliti menggunakan ragam buku primer dan sekunder. Hasil penelitian menemukan bahwa konsep pendidikan kecerdasan interpersonal menurut Mahmud al-Mishri menekankan pendidikan adab dengan prioritas pendidikan adab kepada orangtua, adab kepada guru, adab kepada teman, adab berbicara, adab bercanda dan adab bertemu dan berjabat tangan. Hasil penelitian ini diharapkan berkontribusi besar terhadap pemahaman pendidik bahwa kecerdasan interpersonal sangat berperan penting dalam pembangunan karakter peserta didik sehingga mampu menghadapi berbagai persoalan di lingkungan sekolah maupun di masyarakat sekitarnya.
\end{abstract}

Kata kunci: Kecerdasan Interpersonal, Remaja Awal, Mahmud al-Mishri.

\section{PENDAHULUAN}

Pendidikan merupakan sebuah proses transfer nilai dan ilmu sebagai bentuk kebudayaan di dalam peradaban manusia. Pendidikan juga merupakan pengembangan dan pembinaan akhlak manusia, di mana di dalamnya terjadi proses pelatihan dan pembiasaan kepada setiap orang yang mengeyam pendidikan ${ }^{1}$. Pada dasarnya perkembangan ilmu pengetahuan akan bermuara pada sebuah penemuan ide-ide. Penemuan ide-ide merupakan cikal bakal dari salah satu bentuk kreasi akal budi (filsafat) manusia, sedangkan alat yang dijadikan untuk berfilsafat tidak lain adalah akal

1 Kama Abdul Hakam, "Tradition of Value Education Implementation in Indonesian Primary Schools," Journal of Social Studies Education Research 9, no. 4 (2018): 295-318, https://jsser.org/index.php/jsser/article/view/357.

Al-Madrasah: Jurnal Ilmiah Pendidikan Madrasah Ibtidaiyah

Vol. 6, No. 1, Januari-Maret 2022 
Hasbi Indra, Akhmad Alim, Salman Al Farisi : Konsep Pendidikan Kecerdasan Interpersonal Pada Siswa Usia Madrasah Menurut Mahmud Al Mishri

(rasio), dan rasio inilah yang pada akhirnya akan menjadi kerangka acuan (frame of reference) terhadap segala bentuk perbuatan manusia ${ }^{2}$.

Pendidikan berfungsi sebagai stimulan bagi perkembangan budaya dan peradaban manusia, dan merupakan penemu corak manusia dalam peralihan nilai dan pengetahuan. Dalam hal pendidikan, setiap potensi manusia (jasmani dan rohani) diperlakukan sama, terlepas dari betapa pentingnya potensi tertentu. Semua potensi tersebut harus dikembangkan dan dibina melalui pendidikan untuk mencapai tingkat keberhasilan budaya yang sesuai dengan fitrah manusia ${ }^{3}$.

Sangat penting untuk memahami bagaimana seorang pendidik dapat memahami sifat pendekatan dan kaitannya dengan tujuan dasar pendidikan Islam, yaitu untuk menciptakan orang beriman yang selalu siap untuk mengabdi kepada Allah SWT. Prosedur pendidikan nyata yang disebutkan dalam Al-Qur'an, atau diekstrapolasi darinya, harus diketahui oleh guru, dan mereka harus mampu memberikan insentif dan disiplin, yang disebut dalam Al-Qur'an sebagai tsawab dan hukuman (iqab). Memiliki kecerdasan interpersonal yang baik adalah mampu memahami dan berempati dengan emosi orang lain. Memahami dan berkomunikasi dengan orang lain adalah bagian alami dari kondisi manusia. Kapasitas untuk membangun hubungan yang baik dengan rekan-rekan serta kemampuan untuk mengkoordinasikan dan menengahi konflik di antara rekanrekan hanya beberapa keterampilan yang diperlukan. Kecerdasan sosial adalah istilah khas untuk jenis pengetahuan. ${ }^{4}$

Kapasitas untuk mengenali dan menanggapi emosi, temperamen, ambisi, dan keinginan orang adalah bagian penting dari kecerdasan ini. Menurut definisi Gardner, kecerdasan interpersonal lebih mementingkan kemampuan memahami orang lain daripada kemampuan merasakan empati. Dimulai pada usia 12 atau 13 tahun, masa remaja adalah masa perkembangan, pematangan, dan penemuan diri. Antara usia 12 atau 13 dan akhir remaja atau awal dua puluhan, ada fase transisi antara masa kanak-kanak dan kedewasaan. Dalam pengertian ini, kedewasaan mengacu pada lebih dari sekedar kedewasaan fisik; itu juga mengacu pada kematangan sosialpsikologis. Kematangan sosial dan psikologis kini sedang dijajaki, bukan hanya kematangan

\footnotetext{
${ }^{2}$ Ahmad Tafsir, Ilmu Pendidikan dalam Perpektif Islam, ed. oleh Remaja Rosda Karya (Bandung, 2010).

${ }^{3}$ Suzannie K Y Leung dan A Reza Hoshmand, "The Imperative of Arts in General Education: Do the Arts Enhance Quality Learning?," The Journal of General Education 68, no. 3-4 (1 Oktober 2020): 153-68, https://doi.org/10.5325/jgeneeduc.68.3-4.0153.

${ }^{4}$ H.B. Uno, Model Pembelajaran: Menciptakan Proses Belajar Mengajar yang Kreatif dan Efektif (Jakarta: Bumi Aksara, 2007).
}

\section{Al-Madrasah: Jurnal Ilmiah Pendidikan Madrasah Ibtidaiyah}

Vol. 6, No. 1, Januari-Maret 2022 
Hasbi Indra, Akhmad Alim, Salman Al Farisi : Konsep Pendidikan Kecerdasan Interpersonal Pada Siswa Usia Madrasah Menurut Mahmud Al Mishri

fisik. ${ }^{5}$ Ada banyak perubahan psikologis yang dialami remaja, termasuk perubahan intelektual, emosional, dan kesejahteraan sosialnya. Dalam hal transformasi tubuh, organ reproduksi, khususnya, telah berkembang dan sekarang berfungsi dengan baik. Hal ini menunjukan bahwa siswa tersebut tidak memiliki kepekaan terhadap lingkungannya atau rendah terhadap kecerdasan interpersonal.

Menurut al-Mishrí ${ }^{6}$ salah satu solusi untuk perkembangan remaja yaitu dengan memperkenalkannya kepada agamanya yaitu agama Islam, caranya mengenalkan remaja kepada adab-adab sesuai syariat Islam seperti adab berbincang, adab bercanda, adab bermajlis ilmu, adab bertemu dan berjabat tangan, adab, ketika menelpon, adab lisan, adab mendengar, adab menuntut ilmu, adab terhadap teman, guru dan orang tua. Misalnya, jika respons siswa menunjukkan bahwa mereka kurang memiliki kecerdasan interpersonal, itu menunjukkan bahwa mereka belum berhasil belajar bagaimana berinteraksi dengan orang lain.

Penerimaan sosial kelompok akan berdampak negatif jika masalah sosial tidak ditangani. Penyesuaian pribadi dan sosial akan berdampak negatif jika individu terlalu jauh dari norma budaya. Ini juga akan berdampak negatif pada hubungan mereka dengan orang lain. Mereka percaya bahwa mereka yang tidak memiliki kecerdasan sosial lebih cenderung ditolak dalam lingkungan sosial dan masyarakat. Beberapa penelitian menyatakan bahwa orang yang memiliki masalah dalam berinteraksi secara sosial tidak mencari pengobatan sampai mereka berusia dua puluh satu tahun. Efek lain dari tidak menangani masalah sosial adalah orang akan menampilkan perilaku menympnag yang masih merupakan konsekuensi abai terhadap mengelola masalah kecerdasan interpersonal.

Relevansi kecerdasan interpersonal pada remaja awal atau rentang usia 12 sampai 13 tahun sebagai makhluk dengan komponen biopsikososial-spiritual akan dilihat dalam kaitannya dengan bagaimana mereka berkembang menuju kedewasaan, kemandirian, atau tonggak-tonggak lain dalam hidup mereka. Dalam perjalanan masa muda seseorang, berbagai perubahan terjadi dalam kehidupan dan hubungan seseorang. Remaja suka bersosialisasi dengan teman sekelas mereka dalam kelompok kecil sebagai salah satu karakteristik pertumbuhan ini. Masa-masa bergaul dan bergaul dalam kelompok besar ini mungkin telah melemahkan kecerdasan sosial remaja. Hal ini dikuatkan oleh penelitian yang dilakukan oleh Saufi dan Royani ${ }^{7}$ yang

\footnotetext{
${ }^{5}$ Enung Asmaya, “Aktivitas Dakwah Fardiyah Dalam Tinjauan Psikologi,” KOMUNIKA: Jurnal Dakwah dan Komunikasi 1, no. 1 (2016): 99-114, https://doi.org/10.24090/komunika.v1i1.783.

${ }^{6}$ Mahmud Al-Mishri, Adab Al-Thifli Al-Muslim Li as-Shigor Wa al-Kibar (Mesir: Daar Al-Maarif, 2011).

${ }^{7}$ M. Saufi dan Muhammad Royani, "Mengembangkan Kecerdasan Interpersonal Dan Kepercayaan Diri Siswa Melalui Efektivitas Model Pembelajaran PBL," Math Didactic 2, no. 2 (2016): 106-15, https://doi.org/10.33654/math.v2i2.35.
}

\section{Al-Madrasah: Jurnal Ilmiah Pendidikan Madrasah Ibtidaiyah}

Vol. 6, No. 1, Januari-Maret 2022 
Hasbi Indra, Akhmad Alim, Salman Al Farisi : Konsep Pendidikan Kecerdasan Interpersonal Pada Siswa Usia Madrasah Menurut Mahmud Al Mishri

menyatakan urgensi kecerdasan interpersonal bagi keberhasilan belajar siswa dan pengaruhnya terhadap kepercayaan diri siswa baik didalam kelas maupun diluar kelas. Maka dari itu, pendidikan interpersonal memegang peranan penting untuk dilakukan sejak fase remaja awal atau rentang usia 12 sampai 13 tahun. Berkenaan dengan hal ini, Gardner menyatakan yang demikian merupakan bakat yang terkait erat dengan kecerdasan interpersonal, tetapi fokusnya adalah pada individu daripada kelompok. ${ }^{8}$

\section{METODE PENELITIAN}

Metode penelitian yang digunakan dalam artikel ini menggunakan metode kualitatif, yaitu suatu metode yang digunakan untuk menjawab permasalahan secara deskriptif dalam pembahasannya. ${ }^{9}$ Selain itu, penelitian kualitatif menekankan pada penemuan makna daripada generalisasi, sehingga metode pengumpulan data meliputi triangulasi (penggabungan), analisis, dan metode induktif/kualitatif. ${ }^{10}$ Menurut Arikunto ${ }^{11}$ studi eksploratif untuk menemukan fakta baru, penelitian deskriptif mengumpulkan data dari lapangan dan menyajikannya dalam bentuk yang mudah dipahami. Penelitian deskriptif dapat dilihat sebagai jenis penelitian yang paling mendasar. Untuk menjelaskan atau menggambarkan peristiwa aktual, termasuk fenomena ilmiah dan teknologi, yang diciptakan oleh manusia, demonstrasi ini ditampilkan. ${ }^{12}$

\section{HASIL DAN PEMBAHASAN}

\section{A. Temuan penelitian}

Menurut al-Mishri kecerdasan interpersonal adalah adab yang tertanam dalam diri manusia. Selain itu, hasilnya akan melahirkan manusia yang mempunya kepribadian yang baik dan berakhlak. Lebih luas lagi dia akan memperbaiki lingkungan, agama, dan bangsa, itu tahapan yang paling luas, paling tidak ini akan memperbaiki dirinya sendiri.

Adab atau tingkah laku itu sangat penting seseorang dalam menjalani kehidupannya, hal ini merupakan bentuk ketaatan kepada Allah SWT. Dengan adab yang benar manusia dapat menyelamatkan dirinya dari pikiran dan perbuatan yang menyesatkan. Proses penanaman adab

${ }^{8}$ Fitri Oviyanti, “URGENSI KECERDASAN INTERPERSONAL BAGI GURU,” Tadrib III, no. 1 (2017): 75-97, https://media.neliti.com/media/publications/257004-urgensi-kecerdasan-interpersonalbagi-gu-6ea48a10.pdf.

${ }^{9}$ Sugiyono, Metodologi Penelitian Pendidikan, Pendekatan Kuantitatif, Kualitatif dan Riset dan Pengembangan, 25 ed. (Bandung: Alfabeta, 2017).

${ }^{10}$ A Muri Yusuf, Metode Penelitian Kuantitatif, Kualitatif dan Penelitian Gabungan, 4 ed. (Jakarta: Kencana, 2017).

${ }^{11}$ Suharsimi Arikunto, Prosedur penelitian: suatu pendekatan praktik (Jakarta: Rineka Cipta, 1992).

${ }^{12}$ Lexy Moleong, Metode Penelitian Kualitatif (Bandung: Remaja Rosdakarya, 2007).

Al-Madrasah: Jurnal Ilmiah Pendidikan Madrasah Ibtidaiyah

Vol. 6, No. 1, Januari-Maret 2022 
Hasbi Indra, Akhmad Alim, Salman Al Farisi : Konsep Pendidikan Kecerdasan Interpersonal Pada Siswa Usia Madrasah Menurut Mahmud Al Mishri

dalam diri manusia menurut al-Mishri dapat dilakukan melalui proses pengajaran dan pembelajaran yang dilakukan sejak dini. Anak dibiasakan dengan adab dengan kepribadian yang baik, yakni seperti kepribadian Rasulullah SAW atau membentuk kepribadian setiap anak. Proses ini harus berkelanjutan hingga anak tersebut mencapai umur mumayyiz, dalam rangka untuk melatih pikirannyasehingga dapat berfunngsi untuk dapat membedakan antara sesuatu yang baik dan buruk.

Hal ini merupakan suatu proses yang harus dilalui agara jiwa dan akalnya menjadi baik. Jika jiwa dan akalnya sudah berkembang dan menjadi baik maka yangb selanjutnya adalah memasukan ilmu pengetahuan kepada dirinya melalui pendidikan seperti ilmu wajib (fardu'ain) dan memilih bidang keilmuan yang sesuai potensi minat dan bakatnya pada ilmu pengkhususan (fadhu kifayyah $)^{13}$. Menurut pandangan al-Mishri, manusia yang beradab yaitu manusia yang memiliki ilmu dan amal yang benar. Mereka mampu menempatkan segala sesuatu terhadap penilaian yang benar pada tempat dan porsi yang tepat. Maka Konsep Kecerdasan Interpersonal Remaja Awal menurut Mahmud al-Mishri dalam buku Adab al-Thifli al-Muslim adalah sebagai berikut:

\section{1) Adab Terhadap kedua orang tua}

Jika seandainya manusia telah melakukan perjuangan keras dalam rangka memuliakan orang tuanya, hal tersebut tidaklah mungkin bisa memenuhi hak-hak mereka selamanya. Hal tersebut karena mereka memiliki keutamaan yang amat besar setelah Allah subhanahu wa ta'aala ${ }^{14}$. Beberapa adab yang seharusnya dilakukan seorang anak kepada orang tua, yaitu: pertama, Wajib mematuhi perintah orangtua selagi tidak bertentangan dengan aturan Agama Islam. Kedua, Harus menghargai orangtua. Ketiga, Harus Sopan santun. Keempat, Meminta ridhonya. Kelima, Tawadu kepada orangtua. Kelima, tidak menjelekan orang tua. Keenam, tidak bersedih dihadapan orangtua. Ketujuh minta izin ketika akan pergi kepada orang tua ${ }^{15}$.

Senada dengan pemaparan adab seorang anak kepada orang tua dalam perspetif alMishri, Jayana ${ }^{16}$ menjelaskan bahwa ada 7 hal yang harus dilakukan kepada orangtua, diantaranya sebagai berikut:

${ }^{13}$ Al-Mishri, Adab Al-Thifli Al-Muslim Li as-Shigor Wa al-Kibar.

${ }^{14}$ Ibid.

15 Ibid.

${ }^{16}$ Jayana Thoriq Aziz, Adab dan Doa Sehari-hari Untuk Muslim Sejati (Jakarta: PT. Elex Media Kompurindo, 2018).

Al-Madrasah: Jurnal Ilmiah Pendidikan Madrasah Ibtidaiyah

Vol. 6, No. 1, Januari-Maret 2022 
Hasbi Indra, Akhmad Alim, Salman Al Farisi : Konsep Pendidikan Kecerdasan Interpersonal Pada Siswa Usia Madrasah Menurut Mahmud Al Mishri
a) Taat pada perintah orangtua.
b) Jika dalam keburukan, Menolak dengan lembut.
c) Menghormati jika beda Agama.
d) Jangan menyakiti orangtua.
e) Berbicara lembut.
f) Tidak banyak bicara.
g) Berbakti kepada orangtua meskipun orangtua durhaka.

\section{2) Adab Bersilaturahmi}

Adab silaturahmi dan berbuat baik kepada para kerabat merupakan diantara amalan ketaatan yang paling mendekatkan diri kepada Allah SWT Tuhan bumi dan langit. Allah SWT akan senantiasa memudahkan segala urusannya dan menghilangkan rasa sedih yang mendalam 17. Selain itu, Nabi SAW bersabda:

$$
\begin{aligned}
& \text { وبعد أن خلق الله الخلق قال الرحم أيضا: "هل هذا مكان لأولئك الذين يلجئون من تفكك الصداقة (دعم } \\
& \text { الصداقة)." أجاب الله: "صحيح. ألا ترغب في أن أقوم بتوصيل أولئك الذين يربطونك هلك ويقطعون أولئك }
\end{aligned}
$$

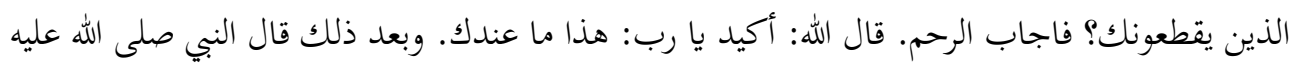

$$
\begin{aligned}
& \text { وسلم: إن شئت فاقرأ الآية التالية: فلو كنت في السلطة تفسد الأرض وتقطع القرابة؟ }
\end{aligned}
$$

Silaturahmi merupakan amalan yang paling cepat mendapatkan pahala. Nabi SAW pun bersabda, "Sesungguhnya balasan yang tercepat dari melakukan ketaatan adalah dengan melakukan silaturrahim. Bahkan jika penghuni suatu rumah itu terdiri dari orang- orang yang banyak dosanya, maka harta mereka bisa menjadi berkembang dan jumlah mereka bisa menjadi banyak apabila mereka bersilaturrahim. Dan tidaklah ada dari penghuni suatu rumah, yang selalu melakukan silaturrahim kemudian mereka menjadi miskin." (HR. Athabary).

Maka selayaknya seorang muslim menjaga kunjungan para kerabatnya. Jika tidak bisa, maka menelepon mereka, atau mengirim pesan singkat. Karena hal ini dapat memperkuat hubungan, menumbuhkan rasa cinta, serta dapat mengingatkan kerabat satu dengan yang lain. Khususnya pada beberapa kesempatan tertentu. Karena hal ini dapat memberikan kebahagiaan bagi mereka.

\section{3) Adab Kepada Guru}

Menurut al-Mishri, adab murid kepada seorang guru itu sangat penting, sebab seorang murid tidak akan bisa mendapatkan ilmu tanpa bantuan oleh seorang guru, tetapi hakikatnya

${ }^{17}$ Al-Mishri, Adab Al-Thifli Al-Muslim Li as-Shigor Wa al-Kibar.

Al-Madrasah: Jurnal Ilmiah Pendidikan Madrasah Ibtidaiyah

Vol. 6, No. 1, Januari-Maret 2022 
Hasbi Indra, Akhmad Alim, Salman Al Farisi : Konsep Pendidikan Kecerdasan Interpersonal Pada Siswa Usia Madrasah Menurut Mahmud Al Mishri

adalah Allah SWT. Salah satu contoh adalah adab murid ketika bertanya, adab murid ketika harus menundukan kepala, adab murid tidak boleh berburuk sangka terhadap guru dalam hal apapun. Tentu saja bukan tidak boleh tetapi ini merupakan adab murid kepada seorang guru. Hal ini seperti perbuatan Nabi Khidir as. sebagai guru dan Nabi Musa as. sebagai murid sebagaimana termaktub dalam ayat 71 surah al-Kahf.

Dalam ayat ini, Allah telah menceritakan dalam Alqur'an Nabi Khidir as. dan Nabi Musa as. Pada saat Nabi Khidir as. dan Nabi Musa as berjalan di tepi pantai dan menemukan perahu, mereka naik perahu, namun setelah tida Nabi Khidir as. Melubanginya. Melihat itu, Nabi Musa as. bertanya, "Mengapa kamu lakukan itu? Akibatnya kamu menenggelamkan penumpangnya yang tidak berdosa. Sesungguhnya kamu telah berbuat kesalahan yang besar." Namun Nabi Khidir as. Mengatakan aku lebih tahu daripada kamu. Hal ini sebagaimana diungkapkan Ibn Jamaah ${ }^{18}$ bahwa adab seorang murid kepada guru, yaitu:

a) Guru harus memiliki sanad Kepada Nabi Muhammad saw.

b) Mematuhi perintah guru dan aturannya.

c) Guru diposisikan lebih mulia dari pada dirinya sendiri.

d) Menghormati guru meskipun sudah meninggal.

e) Selalu sabar dan bersyukur kepada guru yang telah memberikan ilmu.

f) Ketika duduk berbarangan, duduklah dengan santun.

g) Komunikasi dengan adab yang baik.

h) Memperhatikan dengan baik ketika belajar.

i) Jangan menyela pembicaaraan guru.

\section{4) Adab terhadap teman}

Menurut al-Mishri, ${ }^{19}$ adab seseorang terhadap temannya dibagi sebagai berikut, yaitu: Mengutamakan sahabat dari dirinya sendiri, menjaga aibnya, saling mendengarkan ketika berbicara, tidak berdebat, memanggil dengan panggilan nama yang baik, saling mengingatkan pada hal kebaikan, saling mendoakan sesame sahabat, saling sapa ketika bertemu, menyukai dengan tulus sahabat.

Umar bin Achmad Barjah dalam kitab Akhlâq li al-Banîn mejelaskan adab kepada sahabat yaitu Saling menghormati, Saling menasehati, Saling menghormati saudara terhadap yang

\footnotetext{
${ }^{18}$ Rahendra Maya, “Karakter (Adab) Guru dan Murid Perspektif Ibn Jama'ah Al-Syafi'i,” Edukasi Islami: Jurnal Pendidikan Islam 06 (2017): 20.

${ }^{19}$ Al-Mishri, Adab Al-Thifli Al-Muslim Li as-Shigor Wa al-Kibar.
}

\section{Al-Madrasah: Jurnal Ilmiah Pendidikan Madrasah Ibtidaiyah}

Vol. 6, No. 1, Januari-Maret 2022 
Hasbi Indra, Akhmad Alim, Salman Al Farisi : Konsep Pendidikan Kecerdasan Interpersonal Pada Siswa Usia Madrasah Menurut Mahmud Al Mishri

dewasa atau yang masih kecil, menjauhkan dari pertengkaran dan tidak saling menyakiti ${ }^{20}$. Hal tersebut diperkuat oleh pendapat Ismail dan $\mathrm{Azmin}^{21}$ bahwa adab terhadap teman yaitu: pertama, Mengungkapkan rasa kasih sayang dengan baik, dalam hati maupun dalam perbuatan diniatkan karena Allah SWT, kedua, Saling bersilaturahmi atau berkunjung ke rumah, apalagi ketika teman sedang sakit. Keempat, tidak menghina teman. Kelima, Saling mendoakan kebaikan kepada teman, Keenam, dengan kesungguhan ketulusan.

\section{5) Adab berbicara}

Bicara atau berbicara merupakan cara seseorang berkomunikasi satu sama lain. Manusia tidak bias terlepas dari yang namanya komunikasi satu sama lain, sehingga hal ini membuat hal yang paling penting dalam kehidupan. Jika komunikasi gagal dikalangan siswa, maka ini akan menimbulkan permasalahan. Berikut adalah adab-adab dalam berbincara menurut al-Mishri ${ }^{22}$ :
a) Berbicara sesuai dengan akalnya (pengetahuannya)
b) Jelas dalam penyampaian ungkapan
c) Mengulangi perkataan (pembicaraan)
d) Memperhatikan dan menarik perhatian
e) Tidak menyucikan dirinya
f) Mencocokan tema pembicaraan
g) Memperhatikan waktu dan tempat (keadaan)
h) Merendahkan suara dan tidak meninggikannya kecuali dengan hajat (darurat)
i) Jangan mengeluarkan perkataan buruk
j) Tidak memperbanyak debat dan perselisihan
k) Tidak merasa tinggi ketika berbicara
1) Penggunaan kalimat yang santun sampai tujuannya tersampaikan
m) Memanggilnya dengan sebutan terbaik.
n) Tidak mendahului perkataan orng yang lebih tua.
o) Berpaling dari orang-orang bodoh.

\section{6) Adab bercanda}

Al-Mishri mengungkapkan fenomena saat ini yang tidak dapat dipungkiri, dimana banyak ditemui orang-orang tidak lagi memperhatikan etika di dalam bercanda, tidak peduli apa

${ }^{20}$ Muhamad Arif, "Konsep Pendidikan Akhlak dalam Kitab Akhlak Lil Banin Karya Umar Ibnu Ahmad Barjah," Tajdid: Jurnal Pemikiran Keislaman dan Kemanusiaan 02 (2018): 401file://D:/Project/UIKA Bogor/Jurnal/Referensi/.

${ }^{21}$ Muhamad Ismail dan Abdullah Yusof, Azmin, “Adab Unggul Islam dalam Persahabatan Antara Insan," Attarbawiy: Malaysian Online Journal of Education 02 (2017): 102.

${ }^{22}$ Al-Mishri, Adab Al-Thifli Al-Muslim Li as-Shigor Wa al-Kibar.

\section{Al-Madrasah: Jurnal Ilmiah Pendidikan Madrasah Ibtidaiyah}

Vol. 6, No. 1, Januari-Maret 2022 
Hasbi Indra, Akhmad Alim, Salman Al Farisi : Konsep Pendidikan Kecerdasan Interpersonal Pada Siswa Usia Madrasah Menurut Mahmud Al Mishri

yang dia ucapkan, tujuannya adalah bagaimana membuat orang tertawa, walaupun harus menyakiti perasaan orang lain. Sehingga tidak jarang kita saksikan dua orang yang berteman karib tiba-tiba menjadi musuh akibat canda yang kelewat batas ${ }^{23}$. Menurut al-Mishrii ${ }^{24}$ adab-adab yang harus dijaga ketika bercanda adalah sebagai berikut:

a) Tidak menyakiti dengan candaan kita.

b) Tidak mengandung SARA.

c) Tidak menghina sipapun.

d) Jangan terlalu banyak bercanda.

Dalam hal ini bercanda diperbolehkan namun dalam Islam diatur supaya tidak terjadi kekeliruan, sehingga tidak ada orang yang dirugikan. Hal tersebut yang disampaikan oleh, pada initinya bercanda boleh namun empat hal tersebut yang harus diperhatikan.

\section{7) Adab Menuntut Ilmu}

Al-Mishri mengatakan Allah SWT akan mengangkat derajat nabi Adam lebih tinggi dari malaikat, itu karena ilmu. Malaikat diperintahkan untuk bersujud kepada Nabi Adam, seperti itulah awal penciptaan Nabi Adam yang begitu jelas gambarannya. Selain itu, bagaimana dengan manusia seperti kita, jika berpegang teguh dengan ilmu dan semangat dalam mencarinya dengan mengerahkan segala kemampuan, kecuali ia akan diberikan hak untuk menjadi pemimpin di atas muka bumi ini, begitu juga sebaliknya jika manusia bepaling dari ilmu maka hak untuk mendapatkan kepemimpinan tidak ada ${ }^{25}$.

Menurut al-Mishri, terdapat sembilan akhlak yang harus dimiliki seorang yang sedang menimba ilmu, yaitu:

a) Ikhlas karena Allah. Seoarang itu sangat membutuhkan keihklasan yang besar. Maka ,barang siapa yg menuntut ilmu dengan tujuan supaya ia berhasil dalam mengalahkan dunia ini maka dengan itu ia rugi baik di dunia maupun di akhirat dan ia telah menampakkan untuknya azab neraka.

b) Memilih Guru Yang Tepat/Baik. Hendaknya engkau memilih Guru yang dimana engkau belajar dengannya dan Guru yg selalu memperbaiki dirinya, bertakwa, zuhud dan ahli ibadah. Bukan guru yg tujuanya hanya dunia atau guru yg tidak amanah, tidak mempunyai muru'ah (harga diri) dan akhlaq.

c) Menjaga anggota badan dari perkara maksiat. Karena ilmu itu merupakan cahaya yang Allah taruhkan didalam hati orang-orang yang ia kehendaki dari hambanya.
${ }^{23}$ Ibid.
${ }^{24}$ Ibid.
${ }^{25}$ Ibid.

Al-Madrasah: Jurnal Ilmiah Pendidikan Madrasah Ibtidaiyah

Vol. 6, No. 1, Januari-Maret 2022 
Hasbi Indra, Akhmad Alim, Salman Al Farisi : Konsep Pendidikan Kecerdasan Interpersonal Pada Siswa Usia Madrasah Menurut Mahmud Al Mishri

d) Menghindari tidur, makan, bicara yang banyak atau tidak penting yang sepantasnya dilakukan oleh penuntut ilmu adalah menjauhkan dirinya dari tidur yang berlebihan, karena hal itu dapat menyebabkan kemalasan dan terbuangnya banyak waktu dan umur.

e) Memilih teman, memiliki banyak teman, seseorang akan disibukkan oleh pergaulannya dan akan melupakan ilmu. Terlalu banyak bergaul akan menghabiskan waktu dengan hal yang tidak bermanfaat baginya, baik dalam masalah dunia maupun akhirat.

f) Makanan yang baik atau halal, Karena makanan yang haram akan menjadi sebab dicabutnya barokah ilmu dan mengakibatkan kekecewan, dan juga menghalangi diri dari kebaikan yang Allah berikan (Taufiq), juga menjadi sebab terhalangnya doa.

g) Berakhlak mulia, Seorang penuntut ilmu jika ia berakhlak mulia maka Allah akan mencintainya dan ia akan mudah diterima disisi penduduk bumi dan ia akan dicintai oleh gurunya, teman-temannya dan semua orang. Dan ia akan mudah untuk diterima dakwahnya nanti.

h) Menjaga waktu, waktu merupakan hal yang paling penting dalam menuntut ilmu, karena itu para salaf terdahulu mengetahui ketentuan waktu, sehingga mereka tidak menyianyiakannya sedikitpun tanpa faidah. Sebagian mereka berkata “ waktu yang paling berat bagiku adalah satu waktu yang aku gunakan untuk makan.” Maka dari itu menuntut ilmu membutuhkan waktu setiap saat.

i) Adab terhadap guru, Merupakan adab yang mulia yaitu berprilaku baik kepada guru, karena ia merupakan orang yang memberikan kita ilmu.

Sejalan dengan itu, Abudin Nata mengungkapkan agar senantiasa menjunjung adab yang baik bagi siapa saja yang sedang menjalani proses menuntut ilmu. ${ }^{26}$

\section{8) Adab bertemu dan berjabat tangan}

Al-Mishri ${ }^{27}$ mengungkapkan bahwa bahwa adab berjabat tangan merupakan tradisi yang sudah sejak lama ada dalam kehidupan kita, terutama dalam umat Islam. Dalam berbagai kesempatan seseorang bertemu biasanya pasti bersalaman. Hal ini juga yang membuat harus ada aturan jika bersalaman itu ada tujuan yang ingin dicapai. Berikut tujuan biasanya seseorang bersalaman:

a) Bersalaman karena meminta maaf.

b) Bersalaman karena baru bertemu.

${ }^{26}$ Abudin Nata, Perspektif Islam tentang Strategi Pembelajaran (Jakarta: Kencana, 2013).

${ }^{27}$ Al-Mishri, Adab Al-Thifli Al-Muslim Li as-Shigor Wa al-Kibar.

Al-Madrasah: Jurnal Ilmiah Pendidikan Madrasah Ibtidaiyah

Vol. 6, No. 1, Januari-Maret 2022 
Hasbi Indra, Akhmad Alim, Salman Al Farisi : Konsep Pendidikan Kecerdasan Interpersonal Pada Siswa Usia Madrasah Menurut Mahmud Al Mishri

c) Bersalaman karena teman.

d) Bersalaman karena silaturahmi.

\section{9) Adab Ketika Menelepon}

Al-Mishri ${ }^{28}$ mengungkapkan bahwasanya salah satu nikmat Allah kepada manusia adalah adanya alat komunikasi berupa handphone atau telefon. Dengan telepon dapat menghemat waktu, harta, tenaga dan mendekatkan hubungan. Dengan telepon seseorang dapat dengan mudah menghubungi saudara atau temannya meskipun dengan jarak jauh. Dengan waktu singkat seseorang dapat merasa tenang dengan keadaan kerabatnya, atau bertakziyah, atau mendoakan pada suatu kesempatan bahagia, atau berbakti kepada orang tua dengan menanyakan keadannya, atau memutuskan hal penting lewat telepon.

Maanfaat alat komunikasi modern yang sangat banyak tersebutpatut disyukuri, dan rasa syukur tidak sempurna kecuali kita menggunakan dengan ketentuan-ketentuan islam. Dan dari itu kita wajib mempelajari adab-adab islam dalam menggunakan alat komunikasi handphone atau telepon. Berikut adab-adab dalam menggunakan alat komunikasi handphone atau telefon menurut al-Mishri ${ }^{29}$.
a) Meniatkan ikhlas karna Allah.
b) Tidak menelepon lebih dari tiga kali.
c) Tidak menelepon pada jam-jam tertentu.
d) Memperkenalkan diri.
e) Tidak lama dalam menggunakan telepon umum (wartel) tanpa keadaan darurat.
f) Tidak berlama-lamaan dalam menelepon.

\section{KESIMPULAN}

Dari hasil pembahasan di atas dapat disimpulkan bahwa konsep pendidikan kecerdasan interpersonal Mahmud al-Mishri pada fase remaja awal harus memfokuskan pada beberapa adab, yaitu adab kepada orangtua, adab silaturahmi, ada kepada guru, adab kepada teman, adab berbicara, adab menuntut Ilmu, adab menelepon, adab bercanda, dan adab berjabat tangan.

\section{Daftar Pustaka}

Ahmad Tafsir. Ilmu Pendidikan dalam Perpektif Islam. Diedit oleh Remaja Rosda Karya. Bandung, 2010.
28 Ibid.
29 Ibid.

Al-Madrasah: Jurnal Ilmiah Pendidikan Madrasah Ibtidaiyah

Vol. 6, No. 1, Januari-Maret 2022 
Hasbi Indra, Akhmad Alim, Salman Al Farisi : Konsep Pendidikan Kecerdasan Interpersonal Pada Siswa Usia Madrasah Menurut Mahmud Al Mishri

Al-Mishri, Mahmud. Adab Al-Thifli Al-Muslim Li as-Shigor Wa al-Kibar. Mesir: Daar AlMaarif, 2011.

Arif, Muhamad. "Konsep Pendidikan Akhlak dalam Kitab Akhlak Lil Banin Karya Umar Ibnu Ahmad Barjah." Tajdid: Jurnal Pemikiran Keislaman dan Kemanusiaan 02 (2018): 401file:///D:/Project/UIKA Bogor/Jurnal/Referensi/.

Arikunto, Suharsimi. Prosedur penelitian: suatu pendekatan praktik. Jakarta: Rineka Cipta, 1992.

Asmaya, Enung. “Aktivitas Dakwah Fardiyah Dalam Tinjauan Psikologi.” KOMUNIKA: Jurnal Dakwah dan Komunikasi 1, no. 1 (2016): 99-114. https://doi.org/10.24090/komunika.v1i1.783.

Hakam, Kama Abdul. "Tradition of Value Education Implementation in Indonesian Primary Schools." Journal of Social Studies Education Research 9, no. 4 (2018): 295-318. https://jsser.org/index.php/jsser/article/view/357.

Leung, Suzannie K Y, dan A Reza Hoshmand. "The Imperative of Arts in General Education: Do the Arts Enhance Quality Learning?" The Journal of General Education 68, no. 3-4 (1 Oktober 2020): 153-68. https://doi.org/10.5325/jgeneeduc.68.3-4.0153.

Maya, Rahendra. "Karakter (Adab) Guru dan Murid Perspektif Ibn Jama'ah Al-Syafi'i." Edukasi Islami: Jurnal Pendidikan Islam 06 (2017): 20.

Moleong, Lexy. Metode Penelitian Kualitatif. Bandung: Remaja Rosdakarya, 2007.

Nata, Abudin. Perspektif Islam tentang Strategi Pembelajaran. Jakarta: Kencana, 2013.

Oviyanti, Fitri. "URGENSI KECERDASAN INTERPERSONAL BAGI GURU.” Tadrib III, no. 1 (2017): 75-97. https://media.neliti.com/media/publications/257004-urgensikecerdasan-interpersonal-bagi-gu-6ea48a10.pdf.

Saufi, M; dan Muhammad Royani. "Mengembangkan Kecerdasan Interpersonal Dan Kepercayaan Diri Siswa Melalui Efektivitas Model Pembelajaran PBL." Math Didactic 2, no. 2 (2016): 106-15. https://doi.org/10.33654/math.v2i2.35.

Sugiyono. Metodologi Penelitian Pendidikan, Pendekatan Kuantitatif, Kualitatif dan Riset dan Pengembangan. 25 ed. Bandung: Alfabeta, 2017.

Thoriq Aziz, Jayana. Adab dan Doa Sehari-hari Untuk Muslim Sejati. Jakarta: PT. Elex Media Kompurindo, 2018.

Uno, H.B. Model Pembelajaran: Menciptakan Proses Belajar Mengajar yang Kreatif dan Efektif. Jakarta: Bumi Aksara, 2007.

Yusof, Azmin, dan Muhamad Ismail Abdullah. "Adab Unggul Islam dalam Persahabatan Antara Insan.” Attarbawiy: Malaysian Online Journal of Education 02 (2017): 102.

Yusuf, A Muri. Metode Penelitian Kuantitatif, Kualitatif dan Penelitian Gabungan. 4 ed. Jakarta: Kencana, 2017.

Al-Madrasah: Jurnal Ilmiah Pendidikan Madrasah Ibtidaiyah

Vol. 6, No. 1, Januari-Maret 2022 